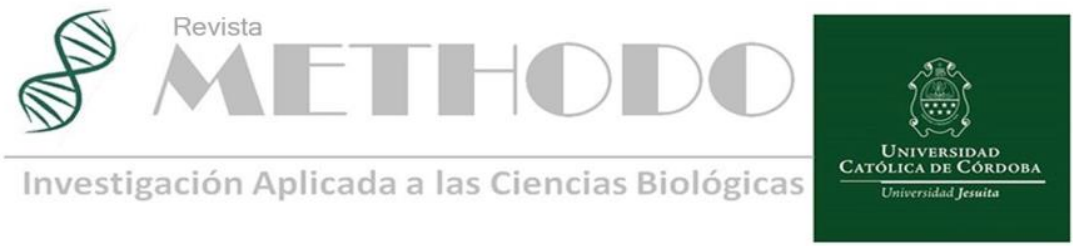

NOTA DE LOS EDITORES Rev. Methodo 2020;5(1):01 https://doi.org/10.22529/me.2020.5(1)01

Redactado 04 Feb. 2020 | Publicado 31 Mar. 2020

Número dedicado a la Educación Universitaria

Number dedicated to University Education

\section{Nota de los editores}

El volumen 5 número 1 de nuestra Revista Methodo Investigación Aplicada a las ciencias biológicas, la iniciamos proponiendo a la comunidad científica y educativa un análisis de diferentes factores que hacen a la Educación Universitaria, en especial de las carreras en ciencias de la salud.

Con este número dedicado, iniciamos una serie de artículos correspondientes a la sección Educación Médica, la cual plasmará un especio crítico en el hacer de la educación superior, que permitirá analizar el cómo y el para qué educamos y el rol de la investigación en la "construcción" de nuestros profesionales.

También este número, es para el equipo editorial una edición especial, dado que la revista, fue indexada en Latindex Catálogo 2.0, logro significativo que categoriza el trabajo de muchos, autores, árbitros, equipo editorial y autoridades universitarias. Haber logrado esta indexación, genera en nuestra labor, por un lado, la alegría del objetivo cumplido que nos abre nuevas puertas, en el "universo" de las publicaciones científicas, y por otro, la obligación a seguir trabajando con el mismo compromiso para concretar nuevos logros que posicionen a nuestra Revista Methodo como una alternativa de calidad para la publicación científica.

Todo es posible, gracias a la comunidad de docente y de investigadores, que desinteresadamente ponen su saber en la construcción de este instrumento de divulgación científica.

En este número 1 del volumen 5 un especial agradecimiento, por un lado, a los autores de cada artículo, por su compromiso con la labor solicitada y disposición a elaborar sus documentos dentro de la normativa que establece el reglamento editorial, y por otro, a los árbitros por su evaluación, responsable y generosa, que garantiza la calidad de lo publicado. Sin autores, sin árbitros, sin equipo editorial esto no sería una realidad.

Esperando puedan disfrutar del trabajo expuesto y se brinde una herramienta que sirva para seguir mejorando nuestro hacer universitario en la formación de profesionales dedicados a las ciencias biológicas, los saludamos cordialmente.

\section{Alejandro Lozano Editor \\ Ricardo J. Saranz Co-editor \\ Fabian C. Saenz}

Co-editor NO 1 Vol. 5 (2020). 